\title{
Inverse correlation between Helicobacter pylori infection and inflammatory bowel disease
}

\author{
L Halme, H Rautelin, M Leidenius, T U Kosunen
}

\begin{abstract}
Aims-To determine the seroprevalence of Helicobacter pylori in patients with Crohn's disease or ulcerative colitis and in controls without inflammatory bowel disease (IBD).

Methods-One hundred consecutive patients with Crohn's disease, 100 consecutive patients with ulcerative colitis, and 100 age and sex matched controls were studied. Serum $H$ pylori IgG and IgA antibody titres were measured by enzyme immunoassay.

Results-The seroprevalence of $H$ pylori was $15 \%$ in patients with IBD $(13 \%$ in patients with Crohn's disease and $18 \%$ in patients with ulcerative colitis), whereas the corresponding figure for the controls was $43 \%$. When compared with controls, the seroprevalence of $\boldsymbol{H}$ pylori in patients with IBD was considerably lower in all age groups tested. There was no important difference in treatment with sulphasalazine or in any other medical therapy administered to $H$ pylori positive and negative patients. At the time of blood sampling there was no difference in the level of education or in the employment status between the patients and the controls. Conclusions-Patients with IBD were less likely to be infected with $H$ pylori than their age and sex matched controls. Neither medical treatment nor socioeconomic factors could explain the difference.

(f Clin Pathol 1996;49:65-67)
\end{abstract}

Keywords: Helicobacter pylori, Crohn's disease, ulcerative colitis, seroprevalence, IgG, IgA.

Fourth Department of Surgery, Helsinki

University Central

Hospital, Helsinki,

Finland

L Halme

$M$ Leidenius

Department of

Bacteriology and

Immunology,

University of Helsinki,

Helsinki, Finland

H Rautelin

T U Kosunen

Correspondence to:

Dr Leena Halme,

Fourth Department of

Surgery, Helsinki

University Hospital,

Kasarmikatu 11-13,

FIN-00130 Helsinki,

Finland.

Accepted for publication

5 September 1995

The cause of inflammatory bowel disease (IBD) is still unknown, although several bacterial and viral agents have been strongly implicated in the aetiology of Crohn's disease..$^{1-4}$ It has also been suggested, however, that the absence of infectious agents ingested in childhood might lead to a functionally impaired mucosal immune system, as is found in patients with Crohn's disease. ${ }^{5}$ El-Omar et al ${ }^{6}$ hypothesised that patients with IBD might be predisposed to gastric mucosal Helicobacter pylori infection; however, they found a surprisingly low prevalence of $H$ pylori in these patients and suggested that this was because of sulphasalazine treatment.

In our previous study we found that gastritis was present at high frequency in gastric mucosa of patients with Crohn's disease but the pre- valence of $H$ pylori was low. ${ }^{7}$ In the present study, we wanted to investigate further the seroprevalence of $H$ pylori in patients with Crohn's disease, in those with ulcerative colitis and in subjects without IBD whose serum samples were collected after an acute episode of diarrhoea.

\section{Methods}

Frozen serum samples for $H$ pylori serology were available from 200 consecutive patients with previously diagnosed IBD (100 patients with Crohn's disease' and 100 further patients with ulcerative colitis). The serum samples were taken between January 1989 and November 1994 and were kept at $-20^{\circ} \mathrm{C}$ before use. To register all possible drug treatment regimens, the patients were interviewed and their medical records re-examined prior to sample collection.

Age and sex matched control serum samples were selected from samples collected in 1990 from patients with an acute episode of bacterial diarrhoea. Fifty six per cent of patients and controls were men. The mean age of the patients with IBD was $42 \cdot 9 \pm 14.6$ years and that of controls was $42 \cdot 1 \pm 14 \cdot 7$ years. Serum samples were stored at $-20^{\circ} \mathrm{C}$ before use. The 100 controls resided in the same southern part of Finland as the patients with IBD. As a part of the examination of the enteritis, the patients had completed a questionnaire regarding their personal data, symptoms and possible underlying disorders. None of these patients had a history of IBD.

$H$ pylori IgG and IgA antibodies were measured separately by enzyme immunoassay. ${ }^{89}$ The lower limit of raised titres (expressed as reciprocals) was 700 for IgG and 100 for IgA.

\section{STATISTICAL METHODS}

Pearson's $\chi^{2}$ test, Fisher's exact test and the two tailed $t$ test were used to analyse the results.

\section{Results}

PREVALENCE OF H PYLORI

Fifteen per cent of patients with IBD $(13 \%$ of patients with Crohn's disease and $18 \%$ of those with ulcerative colitis) had raised IgG or IgA, or both, antibody titres against $H$ pylori. The corresponding figure for the controls was $43 \%$ ( $p<0.005)$. The seroprevalence of $H$ pylori in the patients with IBD was significantly lower than in the controls in each age group tested (group 1, 18-25 years; group 2, 26-35 years; group 3, 36-45 years; group 4, 46-55 years; 
Table 1 Elevated IgG and/or IgA antibody titres against $\mathrm{H}$ pylori in 200 patients with IBD and in 100 controls

\begin{tabular}{|c|c|c|c|c|}
\hline \multirow[b]{2}{*}{ Age (years) } & \multicolumn{2}{|c|}{ No. of antibody positive patients with } & \multirow{2}{*}{$\begin{array}{l}\text { No. of antibody positive } \\
\text { controls }\end{array}$} & \multirow[b]{2}{*}{$p^{*}$} \\
\hline & Crohn's disease & Ulcerative colitis & & \\
\hline $18-25$ & $0 / 10(0 \%)$ & $0 / 7(0 \%)$ & $3 / 11(27 \%)$ & $<0.05$ \\
\hline $26-35$ & $1 / 34(3 \%)$ & $3 / 19(15 \%)$ & $9 / 30(30 \%)$ & $<0.03$ \\
\hline $36-45$ & $5 / 27(19 \%)$ & $1 / 30(3 \%)$ & $9 / 26(35 \%)$ & $<0.03$ \\
\hline $46-55$ & $4 / 13(31 \%)$ & $4 / 19(21 \%)$ & $9 / 16(56 \%)$ & $<0.005$ \\
\hline $56-65$ & $3 / 8(37 \%)$ & $5 / 16(31 \%)$ & $6 / 8(75 \%)$ & $<0.05$ \\
\hline$>65$ & $0 / 8(0 \%)$ & $5 / 9(56 \%)$ & $7 / 9(78 \%)$ & $<0.03$ \\
\hline All & $13 / 100$ & $18 / 100$ & $44 / 100$ & $<0.005$ \\
\hline
\end{tabular}

$*$ IBD $v$ controls.

group 5, 56-65 years; and group 6, over 65 years; table 1). In age groups 2 and 6 , the seroprevalence of $H$ pylori was significantly lower in patients with Crohn's disease than in controls $(\mathrm{p}<0 \cdot 01)$. In age groups 3 and 4 , the seroprevalence of $H$ pylori was significantly lower in patients with ulcerative colitis than in age and sex matched controls $(\mathrm{p}<0.05)$. Of the 31 patients with IBD with positive serology, 17 had raised IgG and IgA titres, 11 had raised IgG titres and three had raised IgA titres. The corresponding figures for the 43 seropositive controls were 29,10 and 4 , respectively.

The mean age of the $31 \mathrm{H}$ pylori positive patients with IBD was $52 \cdot 8 \pm 12 \cdot 8$ years and that of $H$ pylori negative patients was $41.0 \pm 13.6$ years $(\mathrm{p}<0.003)$. Mean duration of IBD was $12 \cdot 0 \pm 7 \cdot 0$ years in $H$ pylori positive and $9 \cdot 5 \pm 8 \cdot 1$ years in $H$ pylori negative patients (NS). Mean age of the seropositive controls was $48 \cdot 0 \pm 16 \cdot 0$ years and that of the seronegative controls was $37 \cdot 7 \pm 11 \cdot 8$ years $(p<0 \cdot 003)$.

PREVIOUS MEDICAL TREATMENT

None of the patients with IBD had undergone treatment for $H$ pylori infection; none had received bismuth or acid suppressive agents combined with antimicrobial agents. Medical treatment for IBD is presented in table 2 . For any of the medical treatment regimens shown, there was no significant difference between

Table 2 Previous medical treatment for IBD in $\mathrm{H}$ pylori positive and negative patients. Therapies longer than a month are included. There was no significant difference between the groups

\begin{tabular}{lll}
\hline & No. of patients \\
\cline { 2 - 3 } Medical therapy & $\begin{array}{c}\text { H pylori positive } \\
(n=31)\end{array}$ & $\begin{array}{l}\text { H pylori negative } \\
(n=169)\end{array}$ \\
\hline Sulphasalazine & $21(68 \%)$ & $88(52 \%)$ \\
5-ASA & $6(19 \%)$ & $39(23 \%)$ \\
Steroids & $10(31 \%)$ & $45(27 \%)$ \\
Long term antibiotics* & $3(10 \%)$ & $15(9 \%)$ \\
Immunosuppressive drugs & 0 & $4(3 \%)$ \\
\hline
\end{tabular}

* Metronidazole, ciprofloxacin or ofloxacin.

Table 3 Education level of patients with IBD and controls. There was no significant difference between the groups

\begin{tabular}{lclc}
\hline Education & $\begin{array}{l}\text { Crohn's disease } \\
(n=100)\end{array}$ & $\begin{array}{l}\text { Ulcerative colitis } \\
(n=100)\end{array}$ & $\begin{array}{l}\text { Controls } \\
(n=100)\end{array}$ \\
\hline University degree & 7 & 14 & 5 \\
Other theoretical & 48 & 41 & 40 \\
Skilled worker & 31 & 38 & 39 \\
Unskilled worker & 14 & 7 & 2 \\
Unknown & 0 & 0 & 5 \\
\hline
\end{tabular}

$H$ pylori positive and negative groups. The duration of sulphasalazine treatment in relation to the prevalence of $H$ pylori is shown in the figure. Before blood sampling, $13(42 \%) H$ pylori positive and $68(39 \%) H$ pylori negative patients had undergone gastrointestinal surgery on one or more occasions (NS).

\section{SOCial STATUS}

There was no difference in the level of education between the patients with IBD and the controls (table 3). At blood sampling, there was no significant difference between the patients and controls with respect to employment status (table 4 ).

\section{Discussion}

Our results show that the prevalence of serum $\operatorname{IgG}$ and IgA antibodies directed against $H$ pylori was significantly lower in patients with

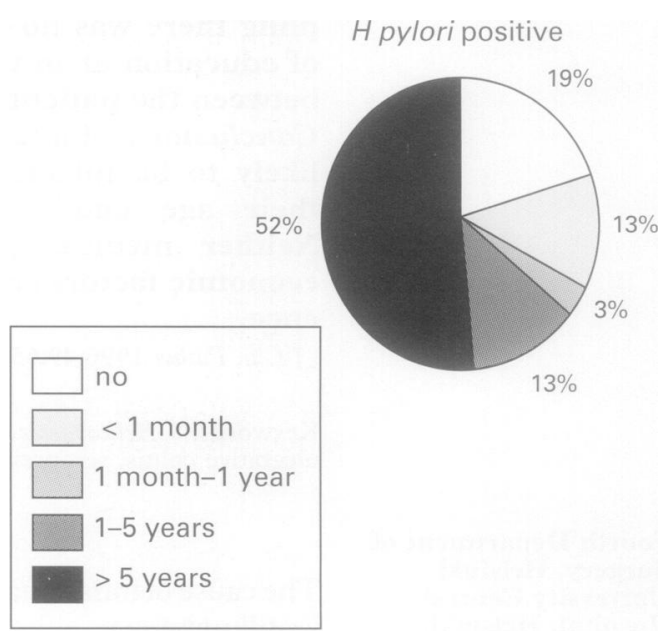

\section{H pylori negative}

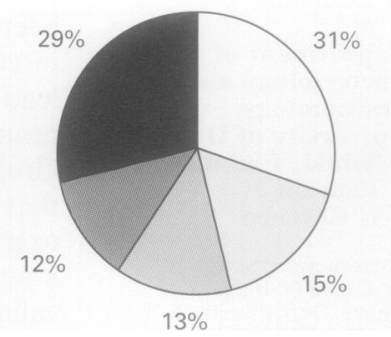

Duration (less than one month, one to 12 months, one to five years, more than five years) of sulphasalazine treatment in $\mathrm{H}$ pylori positive and negative patents. Only uninterrupted periods are included. Patients with adverse events are included in the group of one month or less. 
Table 4 Level of employment in patients with Crohn's disease and ulcerative colitis compared to controls. There was no significant difference between the groups

\begin{tabular}{llll}
\hline Employment & $\begin{array}{l}\text { Crohn's disease } \\
(n=100)\end{array}$ & $\begin{array}{l}\text { Ulcerative colitis } \\
(n=100)\end{array}$ & $\begin{array}{l}\text { Controls } \\
(n=100)\end{array}$ \\
\hline Employed & 72 & 77 & 79 \\
Unemployed & 0 & 0 & 0 \\
Housewife & 3 & 0 & 0 \\
Student & 8 & 5 & 8 \\
Disabled* & 9 & 3 & 1 \\
Pensioner & 8 & 15 & 12 \\
\hline
\end{tabular}

* Patients who were out of work for more than six months were included.

IBD than in age and sex matched controls. Although an age dependent increase in seroprevalence was observed in both groups, patients with IBD had raised $H$ pylori antibody titres significantly less often than controls. The present study confirms our previous findings in patients with Crohn's disease ${ }^{7}$ and the earlier findings of other authors in patients with IBD. ${ }^{6}$ In the present study serum samples from age and sex matched patients with acute bacterial diarrhoea were used as controls. Both the patients and the controls resided the same part of Finland.

In an earlier study, we demonstrated an age dependent increase in $H$ pylori antibody titres in Finnish blood donors. ${ }^{8}$ Although only blood donors with IgG titres of 900 or higher were regarded as positive, the seroprevalence of $H$ pylori was higher in the blood donors than in patients with IBD in each age group tested.

El-Omar et al ${ }^{6}$ suggested that the low prevalence of $H$ pylori antibodies in patients with IBD was a result of long term treatment with sulphasalazine. However, in their study $H$ pylor was resistant to sulphasalazine in vitro and $H$ pylori infection could not be eradicated with sulphasalazine treatment alone. In the present study, most of the $H$ pylori positive patients had been treated with sulphasalazine for one year at least. Furthermore, $H$ pylori positive patients underwent treatment with sulphasalazine more regularly than $H$ pylori negative patients, although the difference was not significant. Taha et $a l^{10}$ were unable to demonstrate that the prevalence of $H$ pylori was lower in patients with rheumatoid arthritis undergoing treatment with sulphasalazine. In our study none of the treatment regimens were associated with a low $H$ pylori seroprevalence. Corticosteroids suppress epithelial proliferation, which is thought to render the mucosa susceptible to the effects of ulcerogens. ${ }^{11}$ However, in our study there was no significant difference in $H$ pylori status between patients taking and those not taking steroids.

In Denmark, patients with Crohn's disease were found to belong to higher socioeconomic groups than controls. ${ }^{12} H$ pylori, on the contrary, has been found to be more frequent in lower socioeconomic groups. ${ }^{13}$ The recent reports of decreasing seroprevalence of $\mathrm{H}$ pylori in developed countries (unpublished data) ${ }^{14}$ could be because of improved standards of living. In our study, however, there was no difference either in education level or em- ployment status for patients with IBD and controls; a similar classification was used as in the Danish study (tables 3 and 4). However, as childhood seems to be the critical period for the acquisition of $H$ pylori infection, ${ }^{14-16}$ living conditions in childhood rather than those in adult life could play a major role. Absence of a hot water supply in the childhood home was shown to be a risk factor for $H$ pylori infection in England, ${ }^{17}$ whereas Gent et $a l^{5}$ found that patients with Crohn's disease had had very high level of domestic hygiene in their childhood, more often having hot running water and separate bathrooms than controls. Unfortunately, the childhood living conditions of the subjects in the present study could not be traced. It is tempting to speculate that some factors, environmental or pathogenetic, protect against $H$ pylori infection but increase susceptibility to IBD.

In conclusion, patients with.IBD were significantly less likely to be infected with $H$ pylor than controls in all age groups studied, although they showed an age dependent increase in seroprevalence. Neither medical treatment nor socioeconomic factors could explain this difference.

1 Sanderson JD, Moss MT, Tizard ML, Hermon-Taylor J. Mycobacterium paratuberculosis DNA in Crohn's disease Mycobacterium paratuberculd

2 Ibbotson IP, Lowes JR, Chahal H, Gaston JSH, Life P Kumararatne DS, et al. Mucosal cell-mediated immunity to mycobacterial, enterobacterial and other microbial antigens in inflammatory bowel disease. Clin Exp Immunol 1992;87:224-230

3 Giaffer MH, Holdworth CD, Duerden BI. Virulence properties of Escherichia coli strains isolated from patients with inflammatory bowel disease. Gut 1992;33:646-50.

4 Ekbom A, Wakefield AJ, Zack M, Adami HO. Perinatal measles infection and subsequent Crohn's disease. Lancet 1994;344:508-10.

5 Gent AE, Hellier MD, Grace RH, Swarbrick ET, Coggon D. Inflammatory bowel disease and domestic hygiene in infancy. Lancet 1994;343:766-7.

6 El-Omar E, Penman I, Cruikshank G, Dover S, Banerjee S, Williams C, et al. Low prevalence of Helicobacter pylori in inflammatory bowel disease: association with sulphasalazine. Gut 1994;35:1385-8.

7 Halme L, Kärkkäinen P, Rautelin H, Kosunen TU, Sipponen $P$. High frequency of helicobacter negative gastritis in patients with Crohn's disease. Gut 1996 (in press).

8 Kosunen TU, Höök J, Rautelin H, Myllylä G. Age-dependent increase of Campylobacter pylori antibodies in blood donors. Scand $\mathcal{f}$ Gastroenterol 1989;24:110-14.

9 Kosunen TU, Seppälä K, Sarna S, Sipponen P. Diagnostic value of decreasing IgG, IgA and $\operatorname{IgM}$ antibody titres after eradication of Helicobacter pylori. Lancet 1992;339: 893-5.

10 Taha AS, Sturrock RD, Russell RI. Helicobacter pylori and peptic ulcers in rheumatoid arthritis patients receiving gold, sulphasalazine and non-steroidal anti-inflammatory drugs. Am $\mathcal{F}$ Gastroenterol 1992;87:1732-5.

11 Eastwood GL. Epithelial renewal in protection and repair of gastroduodenal mucosa. $\mathcal{F}$ Clin Gastroenterol 1991;13 (Suppl 1):48-53.

12 Sörensen VZ, Olsen BG, Binder V. Life prospects and quality of life in patients with Crohn's disease. Gut 1987 28:382-5.

13 Hopkins RJ, Vial PA, Ferreccio C, Ovalle J, Prado P, Sotomayor V, et al. Seroprevalence of Helicobacter pylori in Chile: vegetables may serve as a route of transmission. $\mathcal{F}$ Infect Dis 1993;168:222-6.

14 Banatvala N, Mayo K, Megraud F, Jennings R, Deeks JJ, Feldman RA. The cohort effect and Helicobacter pylori. Feldman RA. The cohort effect
f Infect Dis 1993;168:219-21.

15 Kuipers EJ, Pena AS, van Kamp G, Uyterlinde AM, Pals G, Pels NF, et al. Seroconversion for Helicobacter pylori. Lancet 1993;342:238-41.

16 Mitchell HM, Li YY, Hu PJ, Liu Q, Chen M, Du GG, et al. Epidemiology of Helicobacter pylori in Southern China: Identification of early childhood as the critical period of acquisition. $\mathcal{F}$ Infect Dis 1992;166:149-53.

17 Mendall MA, Goggin PM, Molineaux N, Levy J, Toosy T, Strachan D, et al. Childhood living conditions and Helicobacter pylori seropositivity in adult life. Lancet 1992 339:896-7. 